\title{
Gender Differences in Risk Taking Among Entrepreneurs : Case on Small Medium Enterprise in Malang
}

\author{
Iin Agustina ${ }^{1}$ and Hafid Aditya Pradesa ${ }^{2}$ \\ ${ }^{1}$ Graduate of Magister Management Program, Faculty of Economics and Business, Brawijaya University \\ ${ }^{2}$ Polytechnic of STIA LAN Bandung \\ ${ }^{1}$ Email: ien8307ez@gmail.com \\ 2Email: hafidap85@gmail.com
}

How to cite (in APA style):

Agustina, I., \& Pradesa, H, P.(2020). Gender Differences in Risk Taking Among Entrepreneurs : Case on Small Medium Enterprise in Malang. Warmadewa Management and Business Journal, 2(2) pp.63-72

\begin{abstract}
:
Risk taking considered as one important dimension of entreprenurial orientation. This research aims to study gender differences on risk taking among entrepreneur. The overall objective of this research is to highlight the link between gender difference in risk taking when managing small business. This study utilizes data from 92 entrepreneurs who based in Malang, East Java Indonesia, and operate fashion or handicraft sub-sector of Small Medium Enterprise. Independent Sample T-Test and Confirmatory Factor Analysis was used to explore the phenomenon about whether there is differences in perception among male and female entrepreneur. Descriptive statistic reveals that female entrepreneur scored higher than the male entrepreneur on four of six indicator of risk taking. Eventhough there is no statistical differences in risk taking between male and female entrepreneur is small and the percentage of variance explained is low, there are significant differences in how male and female entrepreneur reflect their risk taking perception found in this study. Overall, these recommendations should help researchers to design and use more relevant risk-taking measures.Conclusions drawn from this study might be useful to better understand the use of risk taking model in entrepreneurial context.
\end{abstract}

Keywords : Risk Taking, Gender Differences, Small Medium Enterprise.

\section{INTRODUCTION}

As focus of the firm, entrepreneurial orientation could describes the tendency to investigate potential opportunities, such as a willingness to consider and analyze the possibility as new entrant to compete in new markets even though doing so might be risky (Lumpkin, G.

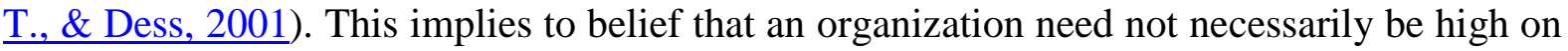
all the entrepreneurial orientation dimensions in order to be considered entrepreneurial. In otherwise, organizations can be more entrepreneurially in different ways (Covin, J.G., Wales, 2018). (Khandwalla PN, 1977) had a similar view; in which entrepreneurially-oriented firms could be distinguish by a decision-making style that is bold, risky, and aggressive.

People have to cope with daily pressure of their surroundings, which is often a stressful experience. Model of managerial attitude towards risk was first recognized in previous studies by (Anderson, B.S., Kreiser, P.M., Kuratko, D.F., Hornsby, J.S., Eshima, 2014), which has been tested as an antecedent of entrepreneurial orientation. In this research, we assume that risk taking is the most important thing in the concept of entrepreneurial orientation and that is why we propose risk taking as a form of independent construct as a derivative of entrepreneurial orientation. (Anderson, B.S., Kreiser, P.M., Kuratko, D.F., Hornsby, J.S., Eshima, 2014) explained about various measures of risk taking that can be used, and perhaps the most straightforward is risk-taking in entrepreneurial orientation. 


\section{Gender Differences in Risk Taking Among Entrepreneurs : Case on Small Medium Enterprise in Malang}

Concept of risk taking is about allocating substantial resources to task in facing uncertain environments (Rauch, A., Wiklund, J., Lumpkin, G. T., \& Frese, 2009). This theory suggests that companies guided by entrepreneurial orientation, on average, will do more unsuccessful activities than more conservative companies (Covin, J.G., Wales, 2018). However, such companies are also more likely than their conservative counterparts to hit economic homeruns, with net results resulting in returns that exceed those obtained by conservative organizations (Covin, J.G., Wales, 2018). Like most humans, entrepreneurs try to avoid risks (Tyszka, T., Cieslik, J., Domurat, A., Macko, 2011). This happened because of risky ventures which they undertake when managing business especially in order to take a chance and reach the business goals in the uncertainty condition.

Risk taking involves the commitment of organization to allocating resources to reach uncertain outcomes. As risk and investment are crucial for the process of economic development (Blakely, E. J., \& Leigh, 2009), SMEs must take calculated risks to make any form of real change in their communities. The definition of economic development requires that changes be made in certain places, and SMEs are inherently in the risk-taking business. SMEs are involved in investing in resources to improve the economic conditions of their communities and directly working to change the status quo. They tend to participate in substantive and risky projects that really affect their communities. SMEs who carry out risky activities are more likely to reap rewards for success than those who do not.

With respect to measuring entrepreneurial orientation, this study offer a reconceptualization of risk taking by addressing various risk taking literature. Under our reconceptualization, we define risk taking in a manner consistent with (Miller D, 1983a), (Covin, J.G., 1989), and (Hughes, M. \& Morgan, 2007) as the joint exhibition of observed entrepreneurial risk taking at the strategic decision-making level favoring actions with uncertain outcomes. This study seeks to explore the construct of risk taking as a stand-alone construct and examine whether there are differences in the sample by gender in perceiving risk taking in the context of small medium enterprise. The present study provided an appropriate context where to examine gender differences, because the participants were homogeneous in terms of background, and the current occupation they experienced. This research aims to study gender differences on risk taking attitudes among entrepreneurs. The overall objective of this research is to highlight the phenomenon about gender and risk taking in entrepreneurship.

\section{LITERATURE REVIEW}

Entrepreneurial orientation can be systematically tested for the impact of each of its aspects relating to strategic decision making (Edmond, V.P., \& Wiklund, 2010) by identifying certain patterns of behavior that are believed to be important to emerge ; (Covin, J. G., \& Slevin, 1991);(Lumpkin, G. T., \& Dess, 2001). In summary, the additional dynamic capabilities of the strategy flexibility of MSMEs can be understood as the primary means of linking entrepreneurial orientation with the exploitation of business opportunities and achievable performance. For risk taking, the items focus on top manager preferences regarding risky projects and a strong tendency to engage in bold action amid uncertainty. They generally try to capture the extent to which an SMES is willing to commit scarce resources to uncertain outcomes.

There is evidence that concept of risk-taking is seems not a well-defined consept(Tyszka, T., Cieslik, J., Domurat, A., Macko, 2011). There is belief that an individual need not show the same risk-propensity or risk-taking. Risk taking concept links to many 


\section{Gender Differences in Risk Taking Among Entrepreneurs : Case on Small Medium Enterprise in Malang}

scholars from different disciplines, each with different views, methods and interests (Thousand Oaks \& Bran, A. , Vaidis, 2019). Furthermore, (Thousand Oaks \& Bran, A., Vaidis, 2019) argued that risk-taking measures have yet to be clearly identified, and the some previous literature (Schoemaker, 1990);(Fox, C. R., 2011); (Schonberg, T., C. R. Fox, 2011) built a thorough overview of the things related to risk taking concept. While another have considered other concepts related when attempting to assess risk-taking (economist traditional : e.g.; human behavior : e.g.(Coppola, 2014); (Szrek, H., L. Chao, S. Ramlagan, 2012)

In entrepreneurship context, risk taking is defined as how managers or entrepreneur want to commit to management and allocating of risk resources that are owned but have a chance of success or failure (Miller D, 1983b). Risk taking is also explained by (Lumpkin, G. T., \& Dess, 2001) as a form of business tendency to face environmental uncertainty or the utilization of most of its resources for business management with results that are either unknown or uncertain. Risk taking has always been a major characteristic associated with entrepreneurship. As the original concept refers to the risk of being an entrepreneur, not working as an employee of someone else. At present, risk taking could be linked to SMEs where managers should make decisions in allocating large amounts of resources to tasks or projects with uncertain results.

(Cantillon, 1931) identified risk taking as the dimension of an entrepreneurial characteristic because it could increased the ability of organizations to increase profits, and organizational profits should be maximized. Organizations describe the characteristics of risk taking by involving their financial and non-financial resources in organizational to overcome uncertain environment (Rauch, A., Wiklund, J., Lumpkin, G. T., \& Frese, 2009). To take entrepreneurial risk, organizations must deviate from the status quo, and the tendency to bear relevant risks would in line with innovation and the growth of entrepreneurial organizations (Covin, J. G., \& Slevin, 1991).

Furthermore, in many society tends to worship risk takers, some of them because the actions taken by heroes are generally portrayed positively in literature and film (Vogler, 1998). But in financial theory has taken a view that seems less risk-laden; it is only the characteristics associated with uncertain events, which illustrate the likelihood of experiencing consequences (good or bad) should someone be involved in the activity (Holton, 2004). Entrepreneurial risk taking has many aspects, in this field can help clarify the many factors that increase or reduce the level of risk in a decision and the role of risk taking in entrepreneurial orientation. Risk taking is ideally a combination of bold steps a company takes in driving business returns. This includes venturing into unknown markets, investing in businesses that have uncertain returns, and borrowing large amounts from the market . Risk taking is not inherently good or inherently bad. An alternative definition that illustrates risk taking is readiness to commit to a large amount of resources (financial and non-financial) for a project or task that might tend to have a higher probability of failure (Tyszka, T., Cieslik, J., Domurat, A., Macko, 2011);(Anderson, B.S., Kreiser, P.M., Kuratko, D.F., Hornsby, J.S., Eshima, 2014); (Covin, J.G., Wales, 2018)). When a business assumes excessive risk by maintaining little control as a result of the power of decision making in the hands of one individual (eg founder), risks that can lead to negative results or have no impact on profitability or growth. Meanwhile, some businesses are too careful when making decisions, such as certain groups, to prevent putting the family's personal wealth at risk. In this case, business is limited to developing reactive strategies (Miller D, 1983a) by introducing changes that are very slow and gradual, which contribute less to business growth. In general, firms built on EO are often classified or characterized by their potential risk taking or strategy. This includes taking large debts or allocating resources for commitments to 
projects that secure a high return on investment in the market then maximizing opportunities in the market. In short, risk taking is a measure of a firm's ability to venture the capital into the unknown and break away from conventional channels. (Hughes, M. \& Morgan, 2007) suggest that entrepreneurial-oriented companies take risks to gain performance gains.(Baker, W. E., Sinkula, 2009) show that following the common pathway leads to high average performance while risk taking has variable outcomes for businesses, including the potential for long-term profits.

Previous studies conducted on gender and the entrepreneurship reported that male are usually more involved in entrepreneurial actions than their female counterparts (Mars, M., \& Metcalf, 2009);(Fairlie, 2014). In line with this idea, based on literature review above, it could be proposed that risk-taking is a specific characteristic of entrepreneurs. On the contrary, entrepreneurs have to deal with risky situations (they simply face them), so they cannot avoid undertaking risky activities in business.

In particular, the evidence from empirical findings so far suggests that risk-taking concept must precisely define what to measure and should be in context-specific risk-taking (Thousand Oaks \& Bran, A. , Vaidis, 2019)This study built conceptual framework of risk taking (see Figure 1) by adopted and integrated previous construct or examined by (Miller D, 1983a). (Covin, J.G., 1989) and (Hughes, M. \& Morgan, 2007) respectively in their concept of risk taking as dimension of entrepreneurial orientation (see Table 1).

Table 1. Construct Operationalization of Risk Taking in This Study

\begin{tabular}{|c|c|c|}
\hline Symbol & Indicators & Adopted From \\
\hline RT1 & $\begin{array}{l}\text { The term "risk taker" is considered a positive attribute for } \\
\text { people in our business. }\end{array}$ & \multirow{3}{*}{$\begin{array}{l}\text { Miller } \\
(1983), \\
\text { Covin and } \\
\text { Slevin } \\
(1989)\end{array}$} \\
\hline RT2 & $\begin{array}{l}\text { People in our business are encouraged to take calculated risks } \\
\text { with new ideas. }\end{array}$ & \\
\hline RT3 & $\begin{array}{l}\text { Our business emphasizes both exploration and experimentation } \\
\text { for opportunities. }\end{array}$ & \\
\hline RT4 & $\begin{array}{l}\text { Strong preference for high-risk projects (with chances of very } \\
\text { high return) }\end{array}$ & \multirow{3}{*}{$\begin{array}{c}\text { Hughes \& } \\
\text { Morgan } \\
(2007)\end{array}$} \\
\hline RT5 & $\begin{array}{l}\text { Believe that wide-ranging acts are necessary to achieve firm's } \\
\text { objectives when situations involving uncertainty }\end{array}$ & \\
\hline RT6 & $\begin{array}{l}\text { Typically adopts a bold, aggresive posture to maximize the } \\
\text { probability of exploiting potential opportunities }\end{array}$ & \\
\hline
\end{tabular}


In this study estimation have assumed that risk taking in entrepreneurial orientation is exhibit utility that is additively separated from risk preferences and risk attitudes. In a model of relative risk taking, we assume that previous findings from (Miller D, 1983a),(Covin, J.G., 1989)) and also (Hughes, M. \& Morgan, 2007) have empirical evidence about good discriminant validity and reliability of risk taking construct. An overview of conceptual framework that examined in this study is provided in Fig.1. In this study investigated six main factors for their risk taking among entrepreneur.

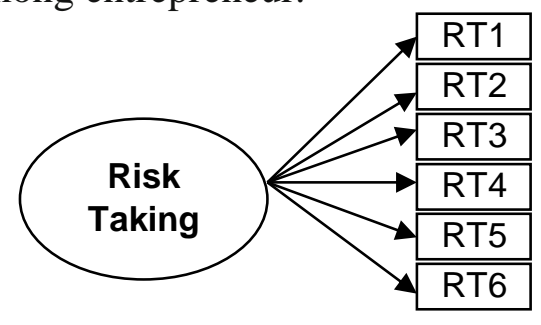

Figure 1. Conceptual Framework

\section{METHOD}

This quantiative, cross-sectional and survey-based study was based on a conceptual framework designed to test discriminant validity and confirm factorial model of risk taking. Thus, this study also examined gender differences about risk taking perceived by entrepreneur.

\section{Procedure}

Data were collected using a confidential and anonymous questionnaire. Participants were informed about the confidentiality of data and its use for research purposes. Respondents were randomly chosen from entrepreneur from small medium enterprise in Malang. The final sample is $N=92(\mathrm{n}$ male $=48$ and $\mathrm{n}$ female $=44)$.

\section{Participant characteristics}

Respondents were mostly men (52,2\%) while other (47,8\%) are women. About 33,7\% respondents are from fashion industry, while $66,3 \%$ resepondents are from handicraft industry. On average, respondents had been managed in their business about four years.

\section{Measures}

Risk Taking (RT). We measured risk taking based on the deconstruction of the popular three previous scholars that examined risk taking in entreprenurial context such as (Miller D, 1983a), (Covin, J.G., 1989), and (Hughes, M. \& Morgan, 2007) scale into its six item version of the instrument with responses from one to five. A Likert type scale was used to gauge respondent perception. Each item was peer reviewed to determine face and content validity construct validity was determined through the application of principle-components factor analysis with varimax rotation.

\section{Data Analysis}

Independent T-test used in this study to examine the gender differences among two categorized samples (male and female entrepreneur). A confirmatory factor analysis (CFA) was also conducted with AMOS 5.0. to test the fit of the six-factor model to the data. After confirmation of the factorial validity of the Risk Taking, we examined the scale means and variances and internal consistencies 


\section{RESULT AND DISCUSSION}

Univariate results yielded significant gender differences on risk taking measures (Table 1). For risk taking, men scored higher then women for two items : (1) people in our business are encouraged to take calculated risks with new ideas and (2) strong preference for high-risk projects (with chances of very high return). However, female entrepreneur as surprisingly reported higher frequency in four of six item of risk taking then male entrepreneur.

Table 2. Descriptive Statistic, Mean, Independent Sample T-Test for Indicators

\begin{tabular}{|c|c|c|c|c|}
\hline & \multirow[b]{2}{*}{$\begin{array}{c}\text { Mean } \\
\mathrm{N}= \\
92\end{array}$} & \multicolumn{2}{|c|}{ Mean } & \multirow{2}{*}{$\begin{array}{l}\text { t-test for } \\
\text { Equality } \\
\text { of Means } \\
\text { (Sign) }\end{array}$} \\
\hline & & $\begin{array}{c}\text { Male } \\
\mathrm{n}= \\
48\end{array}$ & $\begin{array}{c}\text { Female } \\
\mathrm{n}=44\end{array}$ & \\
\hline $\begin{array}{l}\text { The term "risk taker" is considered a positive } \\
\text { attribute for people in our business. }\end{array}$ & 4.05 & 4.00 & 4.11 & .144 \\
\hline $\begin{array}{l}\text { People in our business are encouraged to take } \\
\text { calculated risks with new ideas. }\end{array}$ & 4.27 & 4.29 & 4.25 & .338 \\
\hline $\begin{array}{l}\text { Our business emphasizes both exploration } \\
\text { and experimentation for opportunities. }\end{array}$ & 3.61 & 3.48 & 3.75 & .132 \\
\hline $\begin{array}{l}\text { Strong preference for high-risk projects (with } \\
\text { chances of very high return) }\end{array}$ & 3.79 & 3.83 & 3.75 & .468 \\
\hline $\begin{array}{l}\text { Believe that wide-ranging acts are necessary } \\
\text { to achieve firm's objectives when situations } \\
\text { involving uncertainty }\end{array}$ & 3.72 & 3.67 & 3.77 & .238 \\
\hline $\begin{array}{l}\text { Typically adopts a bold, aggresive posture to } \\
\text { maximize the probability of exploiting } \\
\text { potential opportunities }\end{array}$ & 3.62 & 3.58 & 3.66 & .286 \\
\hline Mean & 3.84 & 3.80 & 3.88 & \\
\hline
\end{tabular}

Considering descriptive statistic, female entrepreneur were more likely to take the risk then men to female (mean female $=3.88$, mean male $=3.80$ ). Female entrepreneur are more believe that "risk taker" is considered a positive attribute for people in our business and believe that wide-ranging acts are necessary to achieve firm's objectives. Female entrepreneur also agree that their business emphasizes both exploration and experimentation for opportunities, besides that typically adopts a bold, aggresive posture to maximize the probability of exploiting potential opportunities.

Table 3. Independent Sample T-Test for Gender

\begin{tabular}{lccc}
\hline & $\begin{array}{c}\text { t-test for Equality of } \\
\text { Meanst }\end{array}$ & df & $\begin{array}{c}\text { Sig. (2- } \\
\text { tailed) }\end{array}$ \\
\hline Risk Taking & -.616 & 89.999 & .540 \\
\hline
\end{tabular}


Therefore, in order to identify whether the dependent and independent variable significant differences existed in terms of risk taking among gender, independent sample t-test was employed to test whether the significant difference exist. From the result, there is no significant differences in risk taking between male and female $(p=0.540,>0.05)$. It is somewhat surprising that both male and female entrepreneur are not different in taking risk when managing business.

The reliability $(\alpha)$ values of risk taking construct in this study were 0.746 . The reliability values were greater than 0.7 (acceptance level). The results showed that the survey questions were all reliable. Confirmatory factor analysis was performed on the survey results to examined factorial score among indicators of variabel. The convergent validity factor loading $\beta$ values were all greater than 0.5. The results showed that the survey questions were related to each other. The discriminant validity factor loading values were all greater than 0.5 for their factors and less than 0.5 for other factors. The results showed that all of the survey questions could be used to determine the desired information.

Table 4. Loading Factor of Risk Taking

\begin{tabular}{|c|c|c|c|}
\hline \multirow[b]{2}{*}{ Item } & \multirow{2}{*}{$\begin{array}{l}\text { Loading } \\
\text { Factor } \\
\left(\mathrm{t}_{\text {statistic }}\right) \\
\mathrm{N}=92\end{array}$} & \multicolumn{2}{|c|}{$\begin{array}{l}\text { Loading Factor } \\
\quad\left(\mathrm{t}_{\text {statistic }}\right)\end{array}$} \\
\hline & & $\begin{array}{c}\text { Male } \\
\mathrm{n}=48\end{array}$ & $\begin{array}{c}\text { Female } \\
\mathrm{n}=44\end{array}$ \\
\hline $\begin{array}{l}\text { The term "risk taker" is considered a } \\
\text { positive attribute for people in our business } \\
\text { (RT1) }\end{array}$ & $\begin{array}{c}0.479 \\
(2.497)\end{array}$ & $\begin{array}{c}0.162 \\
(1.368)\end{array}$ & $\begin{array}{c}0.595 \\
(2.826)\end{array}$ \\
\hline $\begin{array}{l}\text { People in our business are encouraged to } \\
\text { take calculated risks with new ideas (RT2) }\end{array}$ & $\begin{array}{c}0.556 \\
(2.529)\end{array}$ & $\begin{array}{c}0.627 \\
(2.635)\end{array}$ & $\begin{array}{c}0.525 \\
(3.752)\end{array}$ \\
\hline $\begin{array}{l}\text { Our business emphasizes both exploration } \\
\text { and experimentation for opportunities } \\
\text { (RT3) }\end{array}$ & $\begin{array}{c}0.768 \\
(3.712)\end{array}$ & $\begin{array}{l}0.552 \\
(2.69)\end{array}$ & $\begin{array}{c}0.736 \\
(8.835)\end{array}$ \\
\hline $\begin{array}{l}\text { Strong preference for high-risk projects } \\
\text { (with chances of very high return) (RT4) }\end{array}$ & $\begin{array}{c}0.568 \\
(2.801)\end{array}$ & $\begin{array}{c}0.155 \\
(0.914)\end{array}$ & $\begin{array}{c}0.776 \\
(7.347)\end{array}$ \\
\hline $\begin{array}{l}\text { Believe that wide-ranging acts are } \\
\text { necessary to achieve firm's objectives when } \\
\text { situations involving uncertainty (RT5) }\end{array}$ & $\begin{array}{c}0.719 \\
(3.406)\end{array}$ & $\begin{array}{c}0.276 \\
(1.108)\end{array}$ & $\begin{array}{c}0.710 \\
(4.165)\end{array}$ \\
\hline $\begin{array}{l}\text { Typically adopts a bold, aggresive posture } \\
\text { to maximize the probability of exploiting } \\
\text { potential opportunities (RT6) }\end{array}$ & $\begin{array}{c}0.706 \\
(3.472)\end{array}$ & $\begin{array}{c}0.508 \\
(2.136)\end{array}$ & $\begin{array}{c}0.680 \\
(4.320)\end{array}$ \\
\hline
\end{tabular}

Regarding the research question of this research, findings show that gender influences aspects regarding the risk taking attitude towards business not confirmed. Although female entrepreneur had a slightly higher average risk taking score $(M=3.80, S D=.884)$ compared to men $(M=3.88, S D=.962)$, the difference was not statistically significant $(t(92)=-.616, p$ $=.540)$. However, findings did show that in categorized sample by gender, result show that all 


\section{Gender Differences in Risk Taking Among Entrepreneurs : Case on Small Medium Enterprise in Malang}

of risk taking indicators have a good discriminant validity. In contrary, male sample show three of six indicator have not a good discriminant validity (factor loading values less than 0.5 ). Risk taking among male entrepreneur consist of RT2 RT3 RT6, while in female entrepreneur sample risk taking consist all of indicators (RT1 to RT6). Risk taking among male entrepreneur most reflected by people in our business are encouraged to take calculated risks with new ideas. Risk taking among female entrepreneur most reflected by strong preference for high-risk projects (with chances of very high return).

Eventhough the statistical differences in risk taking between women and men is small and the percentage of variance explained is low, there are significant differences in loading factors found in this study in each sample. In this study, data observed that most of the respondents who participated in research managed business in two kind of creative sub sector industry, that are fashion and handicraft industry. Although this research not include the categorized of industry in data analysis, the assumptions about sector industry may support our results (no difference in risk taking between male and female entrepreneur) and should be tested with more categorical factors that may influence the differences of risk taking.

\section{CONCLUSION}

There has been an increasing emphasis in the past few decades on the dimension of entrepreneurial orientation. Results described above reflect no existence of differences between male and female entrepreneur in risk taking. In spesifically, findings show no support for the claim that male entrepreneurs are generally more risk-taking than female entrepreneurs. We find specifically that while female entrepreneur show more risk taking, didn't show significant difference in risk taking with male entrepreneur. Females are now getting greater role in the society than before. The results of the study suggest that men and women respond to risk taking in the entrepreneurial environment for slightly different reasons.

While EO scholars generated significant insights about entrepereneurial intention over the past three decades, much work remains to expand our knowledge of entrepreneurial orientation dimension. Objective of this study was to highlight the key points that should be kept in mind when analyzing gender differences by using measures of risk-taking concepts in entrepreneurial orientation. The need for further exploration of risk taking concept in specific context or sample (e.g. female entrepreneur). The need to take into account the subjectivity of risk-taking by gender. Such implications reflect on the nature of risk taking among different samples, which are categorized by gender.

The present study has several limitations. The first limitation is that the self-reported nature of our data does not allow us to determine the possibility that men and women differed only in what they were willing to report. To ensure that the study has not capitalized on chance a future study should perform a confirmatory factor analysis with a larger sample. Therefore, interpretation of the findings needs to bear in mind the non-traditional sampling procedure used. Replicatory factor analytic study on the risk taking in future study by using traditional sampling procedures should be carried out to verify findings of the present study. 
Gender Differences in Risk Taking Among Entrepreneurs :

Case on Small Medium Enterprise in Malang

\section{References}

Anderson, B.S., Kreiser, P.M., Kuratko, D.F., Hornsby, J.S., Eshima, Y. (2014). Reconceptualizing Enrepreneurial Orientation. Strategic Management Journal, DOI: 10.1002/Smj.2298.

Baker, W. E., Sinkula, J. (2009). The Complementary Effects of Market Orientation and Entrepreneurial Orientation on Profitability in Small Businesses. Journal of Small Business Management, 47(4): 443-464.

Blakely, E. J., \& Leigh, N. G. (2009). Planning local economic development: Theory and practice. (fourth ed.) Thousand Oaks, CA: Sage.

Cantillon, R. (1931). Essai sur la nature du commerce en général (H. Higgs, Trans.). London: Macmillan. (Original Work Published 1755).

Coppola, M. (2014). Eliciting Risk-Preferences in Socio-Economic Surveys: How Do Different Measures Perform? Journal of Socio-Economics 48: 1-10. Doi:10.1016/j.Socec.2013.08.010.

Covin, J. G., \& Slevin, D. P. (1991). A conceptual model of entrepreneurship as firm behavior. Entrepreneurship Theory \& Practice.

Covin, J.G., Wales, W. J. (2018). Crafting High-Impact Entrepreneurial Orientation Research: Some Suggested Guidelines. Entrepreneurship Theory and Practice, 1-16.

Covin, J.G., D. P. S. (1989). Strategic Management of Small Firms in Hostile and Benign Environments. Strategic Management Journal 10: Pp. 75-87.

Edmond, V. P., \& Wiklund, J. (2010). The historic roots of entrepreneurial orientation research. In H. Lanström \& F. Lohrke (Eds.). . The Historical Foundations of Entrepreneurship Research (Pp. 142-160). Cheltenham, UK: Edward Elgar.

Fairlie, R. W. (2014). Kauffman index of entrepreneurial activity 1996-2013. Kansas City, MO: Ewing Marion Kauffman Foundation.Retrieved from http://www.kauffman.org.

Fox, C. R., and D. T. (2011). The Elusive Search for Stable Risk Preferences. Frontiers in Psychology, 2: 298. doi:10.3389/fpsyg.2011.00298.

Holton, G. A. (2004). Defining risk. Financial Analysts Journal, 60(6), 19-25. Doi:10.2469/Faj.V60.N6.2669.

Hughes, M. \& Morgan, R. E. (2007). Deconstructing the relationship between entrepreneurial orientation and business performance at the embryonic stage of firm growth. Industrial Marketing Management, 36(5), 651-661.

Khandwalla PN. (1977). Some top management styles, their context and performance. Organization and Administrative Sciences 7: 21-51.

Lumpkin, G. T., \& Dess, G. G. (2001). Linking two dimensions of entrepreneurial orientation to firm performance: The moderating role of environment and industry life cycle. Journal of Business Venturing, 16, 429-451.

Mars, M., \& Metcalf, A. (2009). Entrepreneurship in the contemporary academy. ASHE Higher Education Report, 34(5), 1-88. Doi: 10.1002/Ache.3405.

Miller D. (1983a). The correlates of entrepreneurship in three types of firms. Management Science 29.

Miller D, F. P. (1983b). Strategy-making and environment: the third link. Strategic Management Journal 4: 221-235.

Rauch, A., Wiklund, J., Lumpkin, G. T., \& Frese, M. (2009). Entrepreneurial orientation and business performance: An assessment of past research and suggestions for the future. 
Gender Differences in Risk Taking Among Entrepreneurs :

Case on Small Medium Enterprise in Malang

Entrepreneurship Theory and Practice, 33(3).

Schoemaker, P. (1990). Are Risk-Attitudes Related across Domains and Response Modes? Management Science, 36 (12): 1451-1463. Doi:10.1287/Mnsc.36.12.1451.

Schonberg, T., C. R. Fox, and R. A. P. (2011). Mind the Gap: Bridging Economic and Naturalistic Risk-Taking with Cognitive Neuroscience. Trends in Cognitive Sciences, 15 (1): 11-19. Doi:10.1016/j.Tics.2010.10.002.

Szrek, H., L. Chao, S. Ramlagan, and K. P. (2012). ). Predicting (un)Healthy Behavior: A Comparison of Risk-Taking Propensity Measures. Judgment and Decision Making, 7 (6).

Thousand Oaks, C. S., \& Bran, A. , Vaidis, D. (2019). Assessing risk-taking: what to measure and how to measure it. Journal of Risk Research, Pp. 1-14. DOI: 10.1080/13669877.2019.1591489.V.

Tyszka, T., Cieslik, J., Domurat, A., Macko, A. (2011). Motivation, self-efficacy, and risk attitudes among entrepreneurs during transition to a market economy. The Journal of Socio-Economics 40 (2011) 124-131.

Vogler, C. (1998). The writer's journey: Mythic structures for writers. Studio City, CA: Michael Wiese Productions. 